\title{
Tip 1 Diabetes Mellitus'lu Çocuk ve Adolesan Hastaların Retrospektif Olarak Değerlendirilmesi: Tek Merkez Deneyimi
}

\author{
Retrospective Evaluation of Type 1 Diabetes Mellitus Children and \\ Adolescent Patients: A Single Center Experience
}

\author{
Özlem ARMAN BILIR', Eda MENGEN², PInar KOCAAY², Sadi Mehmet VIDINLISAN³
}

\author{
${ }^{1}$ Ankara Şehir Hastanesi, Çocuk Hastanesi, Çocuk Hematoloji Onkoloji Kliniği, Ankara, Türkiye \\ ${ }^{2}$ Ankara Şehir Hastanesi, Çocuk Hastanesi, Çocuk Endokrinoloji Kliniği, Ankara, Türkiye \\ ${ }^{3}$ Çocuk Sağlığı ve Hastalıkları Uzmanı (Emekli), Ankara, Türkiye
}

\section{Öz}

Amaç: Tip 1 diabetes mellitus (DM), çocukluk çağı ve adolesan dönemde en sık görülen kronik endokrin hastalıklardan birisidir. Diyabetli çocuğun izlemi sırasında amaç; ketoasidoz ve hipoglisemi ataklarının oluşumunu engellemek, hastaların normal büyüme-gelişmesini sağlamak ve kronik komplikasyonların gelişimini önlemektir. Tüm bunları yaparken de çocuğun ruh sağlığının korunması sağlanmalıdır. Bu çalışmada, kliniğimizde takip edilen Tip 1 DM'li çocuk ve adolesan hastaların hastane dosyalarını geriye dönük olarak olarak inceleyerek mevcut durumlarını değerlendirmeyi ve gelişen kronik komplikasyonları tespit etmeyi amaçladık.

Gereç ve Yöntemler: Bu çalışma, Sağlık Bakanlığı Ankara Çocuk Sağlığı ve Hastalıkları Hematoloji Onkoloji Eğitim ve Araştırma Hastanesi, Pediyatrik Endokrinoloji pokliniğinde en az 1 yıllık takibi olan tip 1 DM tanılı olgular ile yapıımıştır. Olguların dosyaları geriye dönük olarak incelendi; fizik muayene bulguları, cinsiyet, yaş, diyabet tanısı konulan yaș, diyabet süresi, kullandıkları insülin miktarı (Ü/kg), kullandıkları insülin rejimi, kan lipid düzeyleri, son bir yıllık HbA1c değerleri, eșlik eden otoimmün hastalıklar ve son retinopati kontrolleri kaydedilmiștir. HbA1c \%6.5-7.5: İyi kontrollü diyabet, HbA1c \%7.6-9: Orta kontrollü diyabet, HbA1c > \%9: Kötü kontrollü diyabet olarak kabul edilmiştir. Nefropati değerlendirmesi için mevcut olan olguların, 24 saatlik idrar ve 24 saatlik tansiyon monitorizasyonu sonuçları kaydedilmiştir

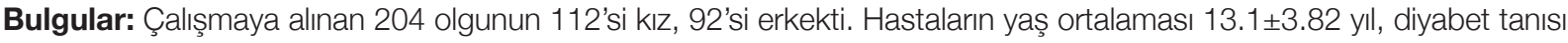


arttığı ancak yaș grupları arasında istatistiksel olarak anlamlı bir fark olmadığı bulundu. Çalıșmaya dahil edilen hastaların

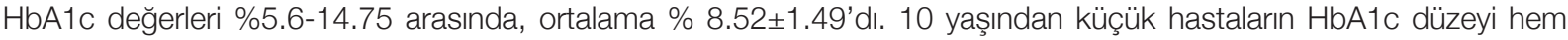
10-15 yaş grubundan ( $p=0.002)$ hem de 15 yaș üstü gruptan ( $p=0.008$ ) daha düşük bulundu. 5 yldan az süren diyabetik olan hastalarda HbA1c düzeyi, hem 5-10 yıl süredir diyabetik gruptan ( $p=0.004$ ) hem de 10 yıldan uzun süredir diyabetik olan gruptan ( $p=0.018$ ) anlamlı olarak daha düşük bulundu. Tip 1 diyabetli olgulara en sık eşlik eden otoimmün hastalıklar otoimmün tiroid hastalığı (\%13.7) ve çölyak hastalığı (\%4.9) olarak bulundu. Retinopati saptanan olgu yoktu. Yüz kırk altı olguda, 24 saatlik idrar toplandı ve glomeruler filtrasyon hızı(GFH) hesaplandı. Bu olguların \% 29.5'inde GFH yüksek saptandı. Glomeruler filtrasyon hızı yüksekliği olan hastalar Evre 1 diyabetik nefropati olarak değerlendirildi. Yüz kırk altı olguda mikroalbumin düzeyleri incelendi ve \%29.5'inde mikroalbuminüri saptandı. Diyabet süreleri ile GFH ve mikroalbuminüri arasında istatistiksel olarak anlamlı fark yoktu. Hastalık kontrolüne göre yaşam içinde kan basıncı izleme(YIKBi) parametreleri değerlendirildiğinde iyi-orta kontrol grubu ile kötü kontrol grubu arasında hipertansiyon açısından istatiksel olarak anlamlı fark görülmedi.

(1)

ARMAN BILIR Ö

MENGENE

KOCAAYP

VIDINLISAN SM
0000-0001-8316-3603 :0000-0003-1597-8418 $0000-0003-0850-0360$ 0000-0002-5113-2789
Çıkar Çatışması / Conflict of Interest: Tüm yazarlar adına, sorumlu yazar çıkar çatışması olmadığııı belirtir.

Etik Kurul Onayı / Ethics Committee Approval: Bu çalıșmada ulusal ve uluslararası etik kurallara uyulmuștur. Çalıșma, Helsinki Bildirgesine dayanan ilkeler baz alınarak etik kurallara uygun olarak yürütülmüș ve S.B. Ankara Çocuk Sağlığı ve Hastalıkları Eğitim ve Araştırma Hastanesi'nden akademik kurul onayı alınmışıtır (18.03.2009, 12 nolu karar).

Yazarların katkısı / Contribution of the Authors: ARMAN BILIR Ö: Araștırma ve/veya makalenin hipotezini veya fikrini olușturan, Sonuçlara ulașmak için planlama/metodoloji belirleme, Araștırma/çalıșmanın sorumluluğunu üstlenmek, ilerlemenin seyrini denetlemek, Hasta takibinde sorumluluk almak,

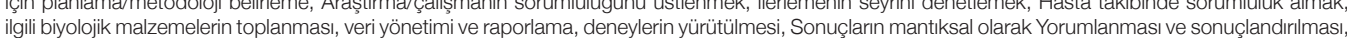
Çalışma için gerekli literatür taramasında sorumluluk almak, Çalışmanın bütününün veya önemli bölümlerinin yazımında sorumluluk almak, Yazım ve dilbilgisi dıșnda bilimsel olarak gönderilmeden önce makaleỷi gözden geçirme. MENGEN E: Sonuçların mantıksal olarak Yorumlanması ve sonuçlandırıması, Çalıșmanın bütününün veya önemli bölümlerinin yazımında sorumluluk almak, Yazım ve dilbilgisi dıșinda bilimsel olarak gönderilmeden önce makaleyi gözden geçirme. KOCAAY P: Sonucların mantıksal olarak Yorumlanması ve sonuçlandııılması, Yazım ve dilbilgisi dıșında bilimsel olarak gönderilmeden önce makaleyi gözden geçirme ViDiNLiSAN SM: Araștırma ve/veya makalenin hipotezini veya fikrini olușturan, Sonuçlara ulașmak için planlama/metodoloji belirleme, Araștırma/çalıșmanın sorumluluğunu üstlenmek, ilerlemenin seyrini denetlemek, Hasta takibinde sorumluluk almak, ilgili biyolojik malzemelerin toplanması, veri yönetimi ve raporlama, deneylerin yürütülmesi.

Atıf yazım şekli / How to cite : Arman Bilir Ö, Mengen E, Kocaay P, Visinlisan S. Tip 1 Diabetes Mellitus'lu Çocuk ve Adolesan Hastaların Retrospektif Olarak Değerlendirilmesi: Tek Merkez Deneyimi. Türkiye Çocuk Hast Derg 2021;15:142-149.
Yazışma Adresi / Correspondence Address:

Özlem ARMAN BíLiR

Ankara Şehir Hastanesi, Çocuk Hastanesi, Çocuk Hematoloji Onkoloji Kliniği, Ankara, Türkiye

E-posta: ozlemarman@gmail.com
Geliş tarihi / Received : 28.12.2020 Kabul tarihi / Accepted : 12.02.2021 Elektronik yayın tarihi $\quad: 25.02 .2021$ Online published

DOI: 10.12956/tchd.845703 
Sonuç: 10 yaşın üzerindeki hastalarda HbA1c değerlerinin yüksek olması, diyabetik adolesan hastaların yönetiminin daha dikkatli yapılması gerektiğini düșündürmektedir. Glomeruler filtrasyon hızı hesaplanan grupta yüksek oranda evre 1 nefropati tespit edilmiş olması diyabetik nefropatinin erken tanınması ve tedavisinin planlanması için hastaların 24 saatlik idrar analizi ile taranmasının önemini göstermiştir. Hastalarımızın \%89.2'nin orta-kötü kontrol grubunda olması takiplerimizin daha titizlikle yapılması gerektiğini, bu hastaların kan lipid düzeylerindeki yüksekliğinin kardiyovasküler hastalıklar açısından önemli risk faktörü olduğu akılda tutulmalıdır. Diyabet izlemi titizlikle ve deneyimli bir ekiple yapılmalıdır. Gelişebilecek komplikasyonların büyük bir bölümü, iyi bir izlemle önlenebilen durumlardır. İyi bir izlem çocuğun fiziksel ve ruhsal olarak sağlıklı bir birey olmasını sağlayacaktır.

Anahtar Sözcükler: Diyabetik komplikasyonlar, Takip, Tip 1 diyabetes mellitus

\section{ABSTRACT}

Objective: Type 1 diabetes mellitus (DM) is one of the most common chronic endocrine diseases in childhood and adolescence. Preventing ketoacidosis and hypoglycemia attacks, ensuring normal growth and development, preventing chronic complication occurrence are the aims of diabetic child follow-up. While doing all these, the mental health of the child should be protected. In this study, we aimed to evaluate the status of pediatric and adolescent patients with Type 1 DM followed up in our clinic and to identify the chronic complications retrospectively by examining the hospital records.

Material and Methods: This study was carried out with cases with type 1 DM who had been followed up for at least 1 year in the pediatric endocrinology clinic of the Ministry of Health, Ankara Pediatric Health and Diseases Hematology Oncology Training and Research Hospital. The files of the cases were analysed retrospectively; physical examination findings, gender, age, diabetes diagnosis age, duration of diabetes, insulin regimen and the amount of insulin usage $(\mathrm{U} / \mathrm{kg})$, blood lipid levels, HbA1c values of the last year, accompanying autoimmune diseases and recent retinopathy controls were recorded. HbA1c percentages are classified as follows; 6.5-7.5\%: Well controlled diabetes, 7.6-9\%: Moderately controlled diabetes and HbA1c> 9\%: Poorly controlled diabetes. For nephropathy evaluation, the 24-hour urine and 24-hour blood pressure monitoring results of the available cases were recorded.

Results: Of the 204 patients included in the study, 112 were female and 92 were male. The mean age of the patients was $13.1 \pm 3.82$ years, the mean age at which they were diagnosed with diabetes was 7.66 \pm 3.81 years, and the mean duration of the disease was 5.52 \pm 3.37 years. It was found that the amount of insulin used increased with age but it was not a statistically significant difference between the age groups. The HbA1c values of the patients included in the study were between $5.6-14.75 \%$, and the average was $8.52 \pm 1.49 \%$. The HbA1c level in patients younger than 10 years old was lower than both $10-15$ year-old group $(p=0.002)$, and patients older than 15 year-old group $(\mathrm{p}=0.008)$. The $\mathrm{HbA} 1 \mathrm{c}$ level in patients with diabetes lasting less than 5 years was found to be lower than both the group with diabetes lasting for $5-10$ years $(p=0.004)$ and the group with diabetes lasting more than 10 years $(p=0.018)$. The most common autoimmune diseases accompanying patients with type 1 diabetes were autoimmune thyroid disease (13.7\%) and celiac disease (4.9\%). There were no cases with retinopathy. In 146 cases, 24-hour urine was collected and the glomerular filtration rate (GFR) was calculated. Glomerular filtration rate was found to be high in $29.5 \%$ of these cases. Patients with high glomerular filtration rate were evaluated as Stage 1 diabetic nephropathy. Microalbumin levels were examined in 146 cases, and microalbuminuria was detected in 29.5\%. There was no statistically significant difference between diabetes duration both GFR and microalbuminuria. There was no statistically significant difference of ambulatory blood-pressure monitoring(ABPM) parameter between the good-moderate control group and the poor control group.

Conclusion: Because of high HbA1c levels in patients older than 10 years, the management of diabetic adolescent patients should be done more careful. The high percentage of stage 1 nephropathy detected in the group whose glomerular filtration rate was calculated showed the importance of screening patients with 24-hour urine analysis for early diagnosis and treatment of diabetic nephropathy. It should be kept in mind that $89.2 \%$ of our patients are in the middle-poor control group, and our follow-ups should be done more meticulously, and the high blood lipid levels of these patients is an important risk factor for cardiovascular diseases. Diabetes monitoring should be done meticulously and with an experienced team. Most of the complications that may develop are conditions that can be prevented with a good follow-up. A good follow-up will ensure that the child becomes a physically and mentally healthy individual.

Key Words: Diabetic complications, Follow-up, Type 1 diabetes mellitus

\section{GiRiş}

Diabetes mellitus terimi, insülin sekresyonundaki, insülin etkisindeki veya her ikisindeki bozukluktan kaynaklanan kronik hiperglisemi ile karakterize edilen karmaşık bir metabolik bozukluğu tarif eder (1). Tip 1 diyabet, kısmen veya çoğu durumda mutlak insülin eksikliğine yol açan, pankreas $\beta$ hücrelerinin kronik immün aracılı yıkımı ile karakterizedir. Değişken bir hızda meydana gelen ve pankreas $\beta$ hücrelerinin yaklaşık \% 90'ı yok edildiğinde klinik olarak semptomatik hale gelen otoimmün aracııı pankreas hücresi yıkımından kaynaklanır (2).
Genel olarak, 15 yaşın altındaki yaklaşık 96.000 çocuğun dünya çapında her yıl tip 1 diyabet geliştirdiği tahmin edilmektedir (3). Çoğu batı ülkesinde, tip 1 diyabet, çocukluk ve ergen diyabetinin \%90'ından fazlasını oluştururken, yaşam süresi boyunca, tip 1 diyabetli bireylerin \% 5 ila \% 10'unu oluşturur (1).

Tip 1 diyabetin etiyolojisi çok faktörlüdür, tip 1 diyabetin altında yatan patojenik süreçlerde genetik yatkınlık, çevresel faktörler, bağıșıklık sistemi ve $\beta$ hücrelerinin spesifik rolleri belirsizliğini korumaktadır. $\beta$ hücre otoimmünitesinin diyabetle ilişkili serolojik belirteçleri olan otoantikorlar arasında, glutamik asit dekarboksilaz 65 otoantikorları (GAD); tirozin fosfataz benzeri insülinoma antijen 2 (IA2); insülin otoantikorları (IAA); ve 
$\beta$-hücresine spesifik çinko taşıyıcı 8 otoantikor (ZnT8) bulunur (4).

Tip 1 DM'li çocuklarda görülen komplikasyonların büyük bir bölümü, iyi bir izlem ile önlenebilen metabolik bozukluklardır. Kötü kontrollü diyabetli bir olguda, akut metabolik etkilerin yanı sıra uzun dönemde kronik komplikasyonlar da görülebilir. Diyabette yaşam süresinin artması, kronik komplikasyonların daha fazla görülmesine neden olmuştur. Diyabetik ketoasidoz (DKA) ve hipoglisemi, akut komplikasyonlardır. Uzun dönem vasküler komplikasyonları ise; retinopati, nefropati, nöropati ve kardiyovasküler hastalıklardır.

$\mathrm{Bu}$ çalışmada kliniğimizde tip 1 DM'li olguların son bir ylllık süre boyunca izlemi, demografik bulguları ve gelişen komplikasyonların poliklinik dosyalarından geriye dönük olarak incelenmesi amaçlanmıştır.

\section{GEREÇ ve YÖNTEMLER}

Bu çalışmada, Sağlık Bakanlığı Ankara Çocuk Sağlığı ve Hastalıkları Hematoloji Onkoloji Eğitim ve Araştırma Hastanesi, çocuk endokrinoloji polikliniğinde takip edilen 204 tip 1 diyabetes mellitus tanilı hastaların dosya verilerinin geriye dönük olarak değerlendirilmesiyle yapılmıştır. En az bir yıldır takipte olan ve poliklinik kontrollerine düzenli gelen olgular çalışmaya dahil edilmiştir. Sendromik diyabetli olgular; Wolcott-Rallison sendromu, Wolfram sendromu ya da DIDMOAD (diabetes insipitus, diabetes mellitus, optik atrofi ve sağırlık), tip 2 diyabetli olgular, MODY tip diyabetli olgular, ikincil nedenlere bağlı gelişen diyabetli olgular (kistik fibrozis, steroid kullanımı) ve dosya verileri yetersiz olan olgular çalışma dışı bırakılmıştır.

Tüm hastaların son kontroldeki; vücüt ağırlı̆ı, boyu, vücut kitle indeksleri (VKI) kaydedilmiş̧ir. Boy ve ağıllık ölçümleri kullanılarak olguların vücut kitle indeksleri (VKI) [Ağırlık (kg)/ Boy² $\left.\left(\mathrm{m}^{2}\right)\right]$ hesaplandı. VKi'leri 95. Persentil ve üzerinde olanlar obez olarak kabul edildi. Persentil değerleri olarak Türk çocukları için belirlenmiş olan persentil eğrileri kullanıldı (5).

Tüm olguların rutin fizik muayeneleri yapıldı. Olguların Tanner evreleme sistemi kullanllarak puberte evrelemeleri yapıldı. Kızlarda meme gelişiminin evre 2, erkeklerde testis volümünün $4 \mathrm{ml}$ olarak saptanması puberte başlangıcı olarak kabul edildi $(6,7)$.

Hastaların dosyalarından tiroid fonksiyon tersleri, tiroid oto antikor düzeyleri ve çölyak hastalı̆ı için otoantikor düzeyleri kaydedildi.

Olguların diyabet tanısı aldıkları yaş, cinsiyet, diyabet süreleri, tanı aldığı mevsim, kullandıkları insülin rejimi ve miktarı Ü/kg şeklinde belirtilmiştir. Hastaların son bir yillık 4 adet HbA1c değerleri, kan lipid düzeyleri, 24 saatlik idrarda mikroalbumin düzeyleri kaydedilmiştir. HbA1c \%6.5-7.5: lyi kontrollü diyabet, HbA1c \%7.6-9: Orta kontrollü diyabet, HbA1c >\%9: Kötü kontrollü diyabet olarak kabul edilmiştir (4). Hastalar, yaşlarına göre $<10$ yaş, 10-15 yaş ve $>15$ yaş olarak, diyabet sürelerine göre de $<5$ yıl, 5-10 yıl > 10 yıl olarak üç gruba ayrımışlardır.

Kan lipid düzeylerinde Amerikan Diyabet Derneği kriterleri dikkate alınmıştır (8). LDL <100 mg/dl, HDL >35 mg/dl, Trigliserid $<150 \mathrm{mg} / \mathrm{dl}$ değerleri normal kabul edilmiștir.

Hastaların 24 saatlik idrar mikroalbumin düzeyleri değerlendirilmiştir.Diyabetik nefropatinin değerlendirilmesi açısından glomeruler filtrasyon hızın (GFH) hesaplanmıştır. Glomeruler filtrasyon hızı,Cocroft-Gault (CG) formulüyle cinsiyet ve vücut yüzey alanı(VYA) kullanılarak hesaplanmıştır (9).

Hastaların24 saatlikkan basıncı ölçümlerininyapılmasınısağlayan yaşam içinde kan basıncı izlemi(Y|KBi) değerlendirilmiştir. Yirmidört saatlik kan basıncı ölçümlerinde ölçülen kan basıncı değerlerinin \% 25'inden fazlasının cins ve boya göre \% 95'in üzerinde olması hipertansiyon (HT) olarak yorumlanmıştır (10).

Göz muayenesi tek bir göz doktoru tarafından değerlendirilmiş ve retinopati var ya da yok olarak belirtilmiştir.

Çalışma, Helsinki Bildirgesine dayanan ilkeler baz alınarak etik kurallara uygun olarak yürütülmüş ve S.B. Ankara Çocuk Sağlığı ve Hastalıkları Eğitim ve Araştırma Hastanesi'nden akademik kurul onayı alınmıştır (18.03.2009, 12 nolu karar).

\section{İstatistiksel Analiz}

Verilerin analizinde SPSS 11.5 programı kullanıımıştır. Sürekli değişkenlerin dağıımının normale yakın olup olmadığı Shapiro Wilk testi ile araştırılı. Varyansların homojenliği ise Levene testiyle incelendi. Tanımlayıcı istatistikler sürekli değişkenler için ortalama \pm standart sapma olarak nominal değişkenler içinse olgu sayısı ve (\%) şeklinde gösterildi. Gruplar arasında normal dağllan sürekli değişkenler yönünden istatistiksel olarak anlamlı farkın olup olmadığı bağımsız grup sayısı iki olduğunda Student's t testi ile ikiden fazla bağımsız grup arasındaki farkın önemliliği ise Tek Yönlü Varyans analizi ile değerlendirildi. Normal dağılmayan sürekli değişkenler yönünden bağımsız iki grup arasındaki farkın önemliliği Mann Whitney $U$ testi ile ikiden fazla bağımsız grup arasında anlamlı farkın olup olmadığı ise Kruskal Wallis testi ile incelendi. Kruskal Wallis test istatistiği sonucunda istatistiksel olarak anlamlı farkın görüldüğü durumlarda parametrik olmayan çoklu karşılaştırma testleri kullanılarak anlamlı farka neden olan grup / gruplar tespit edildi. Nominal değişkenler Pearson'un Ki-Kare testi ile değerlendirildi. Sürekli değişkenler arasındaki doğrusal ilişkinin büyüklüğü Spearman'ın korelasyon testi yapılarak değerlendirildi. $p<0.05$ için sonuçlar istatistiksel olarak anlamlı kabul edildi.

\section{BULGULAR}

Çalışmaya takvim yaşları ortalama 13.1 \pm 3.82 yıl (2.39-18 yıl) olan toplam 204 olgu dahil edilmiştir. Bu olguların 112'si (\% 54.9) kIz, 92' si (\% 45.1) erkektir. Diyabet tanısı aldıkları ortalama 
yaş $7.66 \pm 3.81(0.5-16.34)$ yll, ortalama hastalık süreleri $5.52 \pm$ 3.37 (1-15.25) yıldır. Hastaların önemli kısmının sonbahar ve kış aylarında tanı aldıkları saptandı (\%62). Hastaların \%2'si $(n=4)$ obezdi, \%5.4'ünde boy kısalığı vardı. Çalışmaya alınan hastaların $\mathrm{HbA} 1 \mathrm{c}$ değerleri \%5.6 - 14.75 arasında olup ortalama \%8.52 \pm 1.49 'di. Hastaların \%10.8'i iyi kontrollü diyabet, \% 58.8 'i orta kontrollü diyabet ve \%30.4' ü kötü kontrollü diyabet olarak saptandı.

Hastaların \%83.8'i 4'lü insülin rejimi kullanıyordu (3 doz hızlı etkili, 1 doz uzun etkili), diğer olgularda 2'li (sabah-akşam NPH insülin) ve 3'lü (sabah-akșam hızlı etkili insilin, ve NPH insülin) rejim kullanıyordu. Tip $1 \mathrm{DM}$ tanısıyla izlediğimiz hastalarımızın eșlik eden hastalıklar açısından incelendiğinde \% 13.7 sıklıkla otoimmün tiroidit görüldü. Eșlik eden diğer otoimmün hastalık ise \%4.9 sıkıkla çölyak hastalığıydı. Olguların genel özellikleri Tablo l'de özetlenmiştir.

Tablo I: Olguların genel özellikleri.

\begin{tabular}{|c|c|}
\hline Değişkenler & $\mathrm{n}=204$ \\
\hline $\begin{array}{l}\text { Yaş } \\
<10 \text { yaş } \\
10-15 \text { yaş } \\
>15 \text { yaş }\end{array}$ & $\begin{array}{c}13.1 \pm 3.8(2.4-20.9) \\
39(\% 19.1) \\
99(\% 48.5) \\
66(\% 32.4)\end{array}$ \\
\hline $\begin{array}{l}\text { Cinsiyet } \\
\text { KIz } \\
\text { Erkek }\end{array}$ & $\begin{array}{r}112(\% 54.9) \\
92(\% 45.1)\end{array}$ \\
\hline Tanı Yaşı & $7.7 \pm 3.8(0.5-16.3)$ \\
\hline $\begin{array}{l}\text { Diyabet Süresi } \\
<5 \text { yıl } \\
5-10 \text { yll } \\
>10 \text { yll }\end{array}$ & $\begin{array}{c}5.5 \pm 3.4(1-15.2) \\
98(\% 48.0) \\
87(\% 42.6) \\
19(\% 9.3)\end{array}$ \\
\hline İnsülin Miktarı (Ü/kg) & $0.90 \pm 0.24$ \\
\hline $\begin{array}{l}\text { İnsülin Rejimi } \\
\text { 2'li } \\
\text { 3'lü } \\
\text { 4'lü }\end{array}$ & $\begin{array}{c}5(\% 2.5) \\
28(\% 13.7) \\
171(\% 83.8)\end{array}$ \\
\hline $\begin{array}{l}\text { Ek Hastalık } \\
\text { Otoimmün tiroid hastalığı } \\
\text { Çölyak } \\
\text { Diğer }\end{array}$ & $\begin{array}{l}41(\% 20.1) \\
28(\% 13.7) \\
10(\% 4.9) \\
3(\% 1.5)\end{array}$ \\
\hline $\begin{array}{l}\text { Mikroalbümin (mg/gün) } \\
\text { Normoalbüminüri } \\
\text { Mikroalbüminüri }\end{array}$ & $\begin{array}{c}12.9(0.2-385.9) \\
103(\% 70.5) \\
43(\% 29.5)\end{array}$ \\
\hline $\begin{array}{l}\text { GFH (ml/dk/1.73m²) } \\
\text { Normal } \\
\text { Yüksek } \\
\text { Düșük }\end{array}$ & $\begin{array}{c}136.5(94.0-273.9) \\
95(\% 65.1) \\
43(\% 29.5) \\
8(\% 5.5)\end{array}$ \\
\hline
\end{tabular}

Hastaların kullandıkları insülin miktarı ortalama $0.90 \pm 0.24$ Ü/ kg/gün'dü ve yaş grupları arasında insülin miktarları yönünden istatistiksel olarak anlamlı farkllık yoktu ( $p=0.444)$. Tüm hastalar $<10$ yaş, 10-15 yaș ve $>15$ yaş olarak üç gruba ayrıldı, gruplar arası HbA1c değerleri karşılaştırıldığında, 10 yaş altı olgularda, diğer gruplara göre HbA1c düzeyi istatistiksel anlamlı olarak daha düşük bulundu ( $p<0.05)$ (Tablo II).

Hastaların \%2.5'u 2'li insülin rejimi, \%13.7'si 3'lü insülin rejimi, \%83.8' i 4'lü insülin rejimi kullanmaktaydı. İnsülin rejimi grupları arasında $\mathrm{HbA1c}$ düzeyi yönünden istatistiksel olarak anlamlı farkllık vardı ( $p<0.05)$. 2'li ve 3'lü rejim alanlara göre 4'lü rejim alanlarda HbA1c düzeyi daha yüksekti $(p<0.05)$. 2'li ve 3'lü rejim grupları arasında HbA1c düzeyleri benzerdi (Tablo III).

HbA1c düzeyi açısından <5 yıl diyabetik olan grup ile 5-10 yıl diyabetik olan grup arasında ( $p=0.004$ ) ve $<5$ yıl diyabetik olan grup ile >10 yıl diyabetik olan grup arasında istatistiksel açıdan anlamlı fark görüldü( $p=0.018)$. Beş yıldan az süredir diyabetik olan olguların HbA1c düzeyi daha düşük bulundu. Hastaların diyabet süreleri arttıkça HbA1c düzeyi de artmaktaydı $(r=0.233$ ve $p<0.001)$. Yüz kırk altı olguda 24 saatlik idrarda mikroalbumin düzeyi çalışılmıştı olguların \%29.45'inde mikroalbuminüri, \%29.45'inde GFH yüksek saptandı. Glomeruler filtrasyon hızı yüksek olan hastalar Evre 1 diyabetik nefropati olarak değerlendirildi. Hastalık süresine göre HbA1c, GFH ve mikroalbuminüri düzeyleri karşılaştııldı. Hastaların diyabet süresine göre mikroalbumin ve GFH düzeyleri arasında istatistiksel olarak anlamlı farkllık olmadığı gözlendi ( $p>0.05)$. (Tablo IV).

24 saatlik kan basıncı bakilabilen 49 olgunun 29'unda (\%59.2) hipertansiyon tespit edildi. Yaş grupları arasında YiKKBi değerlendirildiğinde 15 yaş altı grubun \% 50'si hipertansif iken 15 yaş üstü grubun \% 68'i hipertansifti, ancak gruplar arasında istatistiksel açıdan anlamlı fark bulunmadı ( $p>0.05$ ). Yaş grupları arasında dipper ve non dipperlik açısından anlamlı fark bulunmadı ( $p>0.05$ ). Hastalık kontrolüne göre YIKKBi parametreleri değerlendirildiğinde iyi-orta kontrol grubu ile kötü kontrol grubu arasında hipertansiyon açısından istatistiksel olarak anlamlı fark görülmedi ( $p>0.05)$.

Kötü kontrol diyabet grubunun kan lipid düzeyleri iyi ve orta kontrollü diyabete göre daha yüksek saptandı. Mikroalbüminürik ile normoalbüminürik hasta grupları arasında $\mathrm{HbA} 1 \mathrm{c}$ düzeyleri arasında fark saptanmadı (Tablo V).

Tablo II: Yaş grupları ile HbA1c karşılaştıııması.

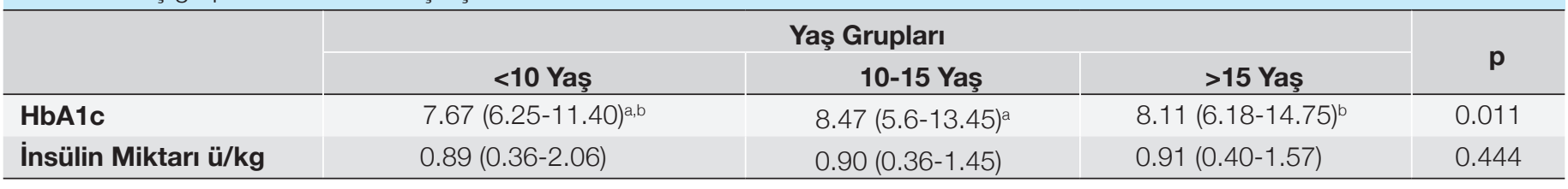

${ }^{a}<10$ yaş grubu ile 10-15 yaş grubu arasındaki fark istatistiksel olarak anlamlı $(p=0.002){ }^{b}<10$ yaş grubu ile $>15$ yaş grubu arasındaki fark istatistiksel olarak anlamlı ( $p=0.008)$. 
Tablo III: Insülin Rejimine Göre HbA1c, Lipid Profili, GFH, Mikroalbümin.

\begin{tabular}{|c|c|c|c|c|}
\hline Değişkenler & 2'li $(n=5)$ & 3'lü (n=28) & 4'lü (n=166) & p \\
\hline HbA1c & $7.5 \pm 0.59^{a}$ & $8.0 \pm 0.98^{b}$ & $8.7 \pm 1.54^{a, b}$ & 0.011 \\
\hline Trigliserid & $89.4 \pm 23.09$ & $92.6 \pm 43.03$ & $115.3 \pm 85.28$ & 0.514 \\
\hline Total Kolesterol & $137.4 \pm 34.62$ & $143.3 \pm 22.30^{b}$ & $163.1 \pm 45.65^{b}$ & 0.042 \\
\hline HDL & $50.8 \pm 9.01$ & $53.8 \pm 14.18$ & $55.0 \pm 12.37$ & 0.656 \\
\hline LDL & $68.8 \pm 27.54$ & $68.9 \pm 19.10^{b}$ & $85.5 \pm 34.07^{b}$ & 0.042 \\
\hline GFH & $183.5 \pm 70.94$ & $165.3 \pm 32.01^{b}$ & $137.5 \pm 27.30^{b}$ & $<0.001$ \\
\hline Mikroalbümin & $12.2 \pm 10.89$ & $15.4 \pm 19.73$ & $33.3 \pm 57.29$ & 0.063 \\
\hline
\end{tabular}

a 2'li rejim grubu ile 4'lü rejim grubu arasındaki fark istatistiksel olarak anlamlı $(p<0.05) .{ }^{\text {b }}$ 3'lü rejim grubu ile $4^{\prime} l u ̈$ rejim grubu arasındaki fark istatistiksel olarak anlamlı $(p<0.05)$.

Tablo IV: DM Süresi Gruplarına Göre HbA1c, GFH ve Mikroalbümin Düzeyleri.

\begin{tabular}{|c|c|c|c|c|}
\hline & \multicolumn{3}{|c|}{ DM Süresi } & \multirow[b]{2}{*}{$\mathbf{p}$} \\
\hline & $<5$ yıl & $5-10 \mathrm{yıl}$ & $>10$ yıl & \\
\hline HbA1c (\%) & $7.87(5.6-14.75)^{a, b}$ & $142.35(97.44-273.91)$ & $12.4(0.3-222.8)$ & 0.006 \\
\hline GFH $\left(\mathrm{ml} / \mathrm{dk} / 1.73 \mathrm{~m}^{2}\right)$ & $8.52(6.38-13.18)^{a}$ & $132.96(94.04-242.91)$ & $11.6(0.2-385.9)$ & 0.127 \\
\hline Mikroalbümin (mg/gün) & $8.8(7.3-12.93)^{b}$ & $133.30(94.14-187.06)$ & $19.0(2.4-137.3)$ & 0.590 \\
\hline
\end{tabular}

${ }^{a}<5$ yll grubu ile 5-10 yll grubu arasindaki fark istatistiksel olarak anlamlı $(\mathrm{p}=0.004)$. ${ }^{b}<5$ yll grubu ile $>10$ yll grubu arasindaki fark istatistiksel olarak anlamlı ( $p=0.018)$.

Tablo V: HbA1c Düzeylerine Göre Lipid Profili, GFH ve Mikroalbümin Düzeyleri.

\begin{tabular}{l|c|c|c|c|}
\hline \multicolumn{1}{c}{ Değişkenler } & İyi Kontrol DM (n=22) & Orta Kontrol DM (n=120) & Kötü Kontrol DM (n=62) & p \\
\hline Trigliserid & $80.6 \pm 41.20^{\mathrm{a}}$ & $97.1 \pm 53.16^{\mathrm{b}}$ & $146.6 \pm 113.43^{\mathrm{a}, \mathrm{b}}$ & $<0.001$ \\
\hline Total Kolesterol & $144.5 \pm 23.89^{\mathrm{a}}$ & $147.2 \pm 25.56^{\mathrm{b}}$ & $187.6 \pm 59.26^{\mathrm{a}, \mathrm{b}}$ & $<0.001$ \\
\hline HDL & $55.7 \pm 11.36$ & $53.3 \pm 11.71$ & $57.1 \pm 13.82$ & 0.137 \\
\hline LDL & $75.9 \pm 22.91 \mathrm{a}$ & $73.8 \pm 20.88^{\mathrm{b}}$ & $101.7 \pm 43.98^{\mathrm{a}, \mathrm{b}}$ & $<0.001$ \\
\hline GFH & $162.5 \pm 140.86$ & $144.4 \pm 49.98$ & $31.6 \pm 30, .42$ & 0.321 \\
\hline Mikroalbümin (mg/gün) & $21.2 \pm 23.80$ & $43.3 \pm 18.61$ & $36.2 \pm 77.34$ & 0.453 \\
\hline
\end{tabular}

a lyi Kontrol DM grubu ile Kötü Kontrol DM grubu arasındaki fark istatistiksel olarak anlamlı $(p<0.01) .{ }^{b}$ Orta Kontrol DM grubu ile Kötü Kontrol DM grubu arasindaki fark istatistiksel olarak anlamlı ( $p<0.001)$.

\section{TARTIŞMA}

Tip 1 DM'nin başlangıç yaşı dünya üzerinde ve ülkemizde bölgesel farkllıklar göstermekle birlikte bimodal dağlım gösterir, 4-6 yaș ve 10-14 yaș olmak üzere iki pik yapmaktadır. Bunun sebebinin okul öncesi dönemde enfeksiyonlar, pubertal dönemde ise büyüme hormonu ve gonadal steroidlerin etkisi olduğu düşünülmektedir. Şimşek ve ark. (11) 46 diyabetli çocuk ile yaptıkları çalışmada diyabet insidansının 6-8 yaş grubunda arttığı bildirilmiştir. Karadağ ve ark. (12) yaptığı diğer bir çalş̧mada en fazla erken çocukluk döneminde (4-6 yaş) diyabet insidansının arttığı gösterilmiştir. Çalışmamızda hastaların tanı yașı ortalaması $7.66 \pm 3.81(0.5-16.34)$ yll ile literatürle uyumlu olarak bulunmuştur.

Kadınları daha sık bir şekilde etkileyen otoimmün bozuklukların çoğunun tam aksine, Tip 1 diyabet insidansı cinsiyet farkllığı popülasyonların hepsinde olmasa da bazılarında bulunur (1).
Hastalığın insidansının yüksek olduğu Finlandiya ve Norveç gibi ülkelerde erkeklerde daha sık olduğu bildirilirken, insidansın düşük olduğu İsrail ve Polonya gibi ülkelerde kılarda daha sık olduğu bildirilmektedir (1). Kandemir ve ark. (13) yaptıkları çalışmada cinsler arasında farklılık olmadığı bildirilmektedir. Bizim çalıșmamızda benzer şekilde hastaların \%54.9'u kız, \%45.1'i erkek olarak bulundu ve cinsiyet açısından anlamlı farklllik gözlenmedi.

Diyabetin başlangıcı mevsimsel özellik gösterir. Vakaların çoğunlukla kış aylarında tanı aldıkları bilinmektedir. Derraik JG ve ark. (14) yaptığı çalıșmada kıș aylarında daha sık görülen viral enfeksiyonlarla Tip 1 DM'nin ortaya çıkışı arasında doğrudan ilişsi olduğunu vurgulamıştır. Çalışmamızda da benzer olarak hastalarımız sıklıkla sonbahar ve kış aylarında tanı almışlardır (\% 62). Bu sonuç soğuk mevsimlerde artan viral enfeksiyonların çapraz reaksiyon ile pankreas $\beta$-hücre harabiyetine yol açı̆̆ı hipotezini desteklemektedir (13). 
Tip 1 diyabetli çocuklar, genel popülasyondaki çocuklara kıyasla, komorbid otoimmün hastalıklar açısından daha yüksek risk altındadır. Tip 1 diyabetli çocukların ve ergenlerin büyük bir kısmında adacık otoantikorlarına ek olarak saptanabilir organa özgü otoantikorlar (örneğin, tiroid, adrenal) vardır ve tip 1 diyabetli hastaların yaklaşık \%25'ine başka bir otoimmün hastalık teşhisi konur. Otoimmün tiroidit hastalı̆ı, tip 1 diyabetli hastalarda görülen en yaygın otoimmün hastalıktır ve bunu çölyak hastalığı izler (15). Eş tanılı otoimmün hastalıklar kadınlarda erkeklere göre daha sık görülür ve yaşla birlikte görülme sıklığı artar (16). Yapılan çalışmalarda, Tip1 DM'li olgularda tiroid otoantikor pozitifliği \%8.0-31.5 aralığında bildirilmektedir $(14,17)$. Bizim çalışmamızda da Tip 1 DM'ye en sık eșlik eden hastalığın otoimmun tiroid hastalığı (\%13.7) olduğu saptanmıştır. Genel populasyonda Çölyak hastalığı görülme oranı \%0.01-0.03 iken, tip 1 DM'li çocuklarda \%1-10 arasında değişir. Bizim hastalarımızda da Çölyak hastalı̆ı̆ı \%4.9 sıklıkla eşlik eden otoimmün hastalıklar arasında ikinci sırada yer almaktadır. Subklinik veya asemptomatik olabilen otoimmün tiroid hastalığı ve çölyak hastalığı gibi sık görülen komorbid durumların düzenli aralıklarla taranması, daha erken teşhis ve tedaviye izin verir. Böylece tip 1 DM'li hastaların metabolik kontrolünün daha iyi olmasına olanak sağlar.

Çocuklar ve erişkinlerde diyabet tedavisinin amacı, kan şekerini olabildiğince normale yakın düzeylerde tutarak diyabetin uzun dönem komplikasyonlarından korumaktır. Kan şekeri kontrolünün en iyi göstergesi $\mathrm{HbA} 1 \mathrm{c}$ değerleridir. HbA1c ölçümleri, hem uzun vadeli komplikasyon riskini değerlendirmek için hem de glisemik kontrolü optimize etmek için gerçek zamanlı bir araç olarak faydalıdır (18). Springer ve ark. (19) yaptığı bir çalışmada düşük sosyoekonomik düzey, büyük yaş, diyabet süresinin uzunluğu, multipl doz insülin enjeksiyonu (subkutan insülin pompa tedavisine göre) ve kız cinsiyetin kötü glisemik kontrol ile ilişkili olduğu gösterilmiștir. Bizim çalışmamızda hastaların ortalama $\mathrm{HbA} 1 \mathrm{c}$ değerleri \%8.52 olarak bulundu. Hastaların \%30.4'ü kötü kontrollü diyabet olduğu saptandı. Fluck ve ark. (20) yaptığı prospektif çalısmada, tip1 DM'li çocukların metabolik kontrolünü etkileyen faktörler incelenmiş (yaş, puberte evresi, cinsiyet, insülin tedavi rejimio) kan şekeri kontrolünün puberte dönemindeki grupta daha zor sağlandığı belirtilmiştir. Bizim çalışmamız da hastaları yaş gruplarına ayırarak HbA1c düzeylerini karşılaştırdığımızda 10-15 yaş ve $>15$ yaş gruplarının $\mathrm{HbA1c}$ düzeylerinin $<10$ yaş grubuna göre daha yüksek olduğunu ve hastaların takvim yaşı büyüdükçe $\mathrm{HbA1c}$ değerlerinin de arttığı bulundu. Bu da hastaların pubertal dönemde kan şekeri kontrolünün daha zor olduğunu desteklemektedir. Springer ve ark. (19) çalışmasında olduğu gibi bizim çalıșmamızda da diyabet süresi arttıkça HbA1c düzeylerinin arttığını görülmüştür. Bunun bir sebebi de ergenlerin hastalı̆ga uyumunun yaş artımı ile birlikte azalması, ergenlik döneminin getirdiği ruhsal sorunlar ve bıkkınlık olabilir.

Optimal metabolik kontrole sahip olmayı amaçlayan, çoklu günlük enjeksiyon kombinasyonları veya bazal ve prandiyal insülinin farklı ikameli pompa terapisi ile uygulanan yoğun insülin rejimleri, pediatrik diyabetolojide tüm yaş grupları için altın standart haline gelmiştir (21). Mortensen ve ark. (22), yaptığı çok merkezli bir çalışmada kullanılan insülin dozunun (Ü/kg/gün) yaşla birlikte arttığı gösterilmiştir. Bizim çalışmamızda kullanılan insülin miktarı ortalama $0.90 \pm 0.24$ Ü/ $/ \mathrm{kg} / g u ̈ n ' d u ̈$, hastaların \%83.8'i 4'lü insülin tedavisi kullanmaktaydı ve yaş grupları ile kullanılan insülin miktarları arasında anlamlı fark saptanmadı. Mortensen ve ark. (22) yaptığı çalışmada farkı insülin rejimleri (günlük 2, 3, 4 ve daha fazla insülin enjeksiyonu) ile glisemik kontrol arasında anlamlı bir ilişki saptanmamıştır. Diyabet kontrol ve komplikasyonları çalışması grubu yoğun insülin tedavisi alan hastaların $\mathrm{HbA1c}$ düzeylerinin konvansiyonel tedavi alanlara göre yaklaşık \%2 oranında daha düşük olduğunu belirtmiştir (23). Ancak bizim çalışmamızda literatürün aksine günlük 2'li ve 3'lü insülin tedavisi alanlara göre 4'lü insülin tedavisi alanların HbA1c düzeyleri daha yüksek saptandı. Bu durum 2' li ve 3' lü insülin rejimi kullanan hasta sayısının az olması ile ilgili olduğu düşünüldü.

Çocuk ve adolesanlarda uzun dönemde gelişen vasküler komplikasyonlar diyabetin mortalitesini belirleyen en önemli faktörlerdendir. Bunlar çocuklukta başlayan retinopati, nefropati, nöropati ve kardiyovasküler hastalıklarıdır. Mikroalbuminüri prevalansının yaş, cinsiyet, diyabet süresi, glisemik kontrol ve pubertal durumla ilişkili olduğu bildirilmiştir. Mikroalbuminürinin pubertal başlangıçlı diyabetlilerde, postpubertal başlangıçılıara göre daha hızlı geliştiğini bunun da pubertal dönemde insülin sensivitesinin azalmasına, diyabet kontrolünün bozulmasına bütün bunların da pubertedeki hormonal değişikliklere bağlı olduğunu belirtilmiştir $(13,22,24)$. Amin ve ark. (25) yaptığı bir çalışmada diyabet tanısından sonraki 10 yılda mikroalbuminüri prevalansı \%25.7, 19 yldan sonra ise \%50.7 olarak bildirilmektedir. Glisemik kontrolün mikroalbuminüri gelişiminde güçlü bir belirleyici faktör olduğunu ve ortalama HbA1c düzeyi <\%8.5 olan ve 20 yaşına gelmiş hastalarda mikroalbuminüri gelişme riskinin \%15 olduğunu bildirilmişdir (25). Bizim çalışmamızda da sıklı̆ı \%29.45 olarak bulundu. HbA1c düzeylerine göre iyi, orta ve kötü kontrollü diyabet olarak gruplandırıldığında gruplar arasında mikroalbuminüri sıkığı açısından ve diyabet süresi ile mikroalbuminüri sıklığı açısından anlamlı fark bulunmadı. Mikroalbuminüri prevalansındaki farkıılığın, çalışmaların yapıldığı populasyonların çeșitliliğine (yaş grupları, diyabet süresi, glisemik kontrolü) ve hastaların takip süresinin farkllığına bağlı olabileceğini düşündük.

Diyabetin başlangıcından sonraki ilk yllarda glomerüler hiperperfüzyon ve renal hipertrofi ortaya çıkar ve bu da klinikte kendini GFH'da artış ile gösterir. Diyabetik hastalarda glomerüler hiperfiltrasyon diyabetik renal hastalık için artmış risk olarak görülür (26). Yapılan prospektif bir çalışmada GFH 125 $\mathrm{ml} / \mathrm{dk}$ 'nın üzerinde olan tip 1 diyabetli hastalarda 8 yıl sonra mikroalbüminüri gelişme sıklĭı \%50 iken, GFH normal olan hastalarda \%5 olarak bulunmuştur (27). Çalışmamızda 204 hastanın 146'sında GFH hesaplandı. Bu hastaların \%29.45'i 
GFH yüksekliği olduğu için evre 1 diyabetik nefropati olarak değerlendirildi. Ancak mikroalbuminürik ve normoalbuminürik hasta grupları arasında GFH yüksekliği açısından anlamlı bir fark bulunmadı.

Diyabetli çocuk ve adolesanlarda kan basıncı ölçümü büyük önem taşır. Çünkü tip 1 diyabet sekonder hipertansiyonun en önemli sebeplerinden birisidir. Persistan mikroalbuminüri hipertansiyon gelişimi ile yakından ilişkilidir, hipertansiyon gelişimi de nefropatinin ilerlemesinde major risk faktörüdür. Lurbe ve ark. (28) yaptıkları çalışmada 24 saatlik kan basıncı ölçümlerinde gece düşüşün azalmasının mikroalbuminüriden önce geliştiğini ve diyabetik böbrek hastalığının erken bir belirleyicisi olduğunu belirtmişlerdir. Hipertansiyonun tedavi edilmesi nefropatinin ilerlemesini yavaşlatır ve var olan erken dönem nefropatinin gerilemesini sağlar (27). Lubre ve ark. (29) yaptıkları çalışmada YIKKBI ile mikroalbuminüri gelișiminden önce uykuda artmıș kan basıncının tespit edilmesinin önemini ve gece artmış kan basıncının diyabetik böbrek hastalığı gelişiminde kilit rol oynadığını vurgulamışlardır. Uyku süresince artmış kan basıncı (yani gece düşüşün olmaması, nondipper) mikroalbuminüri gelişmeden önce görüldüğü ve uyku sırasındaki kan basıncı düşüşünün normale dönmesiyle mikroalbuminüri görülme oranının \%70 azaldığı bildirilmiştir (30). Nitekim normoalbuminürik adolesan ve genç erişkinlerde morfolojik değişiklikler ile nondipperlik ilişkili bulunmuştur, nondipperlik durumunve ortalamagece kanbasıncı yüksekliğinin sonradan gelişen nefropati için erken belirleyici bir parametre olduğu gösterilmiştir (31). Bizim çalışmamızda da hastaların diyabet süreleri ile YIKKBl'nde saptanan hipertansiyon, dipper ve nondipperlik arasında anlamlı fark saptanmamıştır. Mikroalbuminürik grup ile normoalbuminürik grup arasında da hipertansiyon, dipper, nondipperlık arasında istatistiksel olarak anlamlı fark saptanmamıştır. Bu durum belki de hastaların diyabet takip sürelerinin kısa olması ve her bir hastanın izlem süresinin farklı olması ile açıklanabilir.

Diyabetik erişkinlerde kardiyovasküler hastalıklar morbidite ve mortalitenin önde gelen nedeni olmasına rağmen, çocuk ve adolesanlarda nadir görülür. Ancak çocukluk döneminde görülen hiperlipidemi erişkin dönemde ateroskleroz ve kardiyovasküler hastalık riskini artırmaktadır (32). Dislipidemi diyabetik çocuklarda normal çocuklara göre daha yaygındır ve kötü glisemik kontrol ile ilşkilidir (33-35). Maahs ve ark. (33), 2001-2004 yılları arasında 21 yaşından küçük 682 çocukla yaptığı bir çalışmada diyabetik çocuklarda genel populasyona göre total kolestrol düzeyinin daha yüksek, HDL düzeyinin ise daha düşük olduğunu, HbA1c ile total kolestrol düzeyleri arasında önemli bir ilişki olduğunu göstermişlerdir. Bazı klinik ve deneysel çalışmalar diyabetik nefropatinin gelişmesi ve ilerlemesinde hiperlipideminin önemli rol oynadığını gösterilmiştir (36-38). Yüz kırk bir İngiliz çocukla yapılan çalışmada tip 1 diyabet tanısından üç yıl sonra kan lipid düzeylerine bakıldığında hastaların \%15'inde kolesterol, \%18'inde trigliserid, \%8'inde de her ikisi birden yüksek bulunmuştur (34). Bizim çalışmamızda hastaların \%28.4'de trigliserid yüksekliği, \%36.3'nde kolesterol yüksekliği, \%20.1'nde LDL yüksekliği saptandı. Kötü kontrol grubu ile orta ve iyi kontrol grubuna göre trigliserid, kolestrol ve LDL düzeyleri istatistiksel açıdan anlamlı olarak daha yüksekti. Mikroalbüminürik grup ile normoalbuminürik grup arasında hiperlipidemi açısından anlamlı fark bulunmadı. Ancak mikroalbuminürik grubun normoalbuminürik gruba göre LDL düzeyleri daha yüksek bulundu. Bu sonuç literatürde belirtildiği gibi kan şekeri kontrolünün dislipidemi ile yakından ilişkili olduğunu göstermektedir.

Sonuç olarak, diyabet izlemi titizlikle ve deneyimli bir ekiple yapılmalıdır. Hastalarımızın \%89.2'nin orta-kötü kontrol grubunda olması takiplerimizin daha titizlikle yapılması gerektiği, bu hastaların kan lipid düzeylerindeki yüksekliğin kardiyovasküler hastalıklar açısından önemli risk faktörü olduğu akılda tutulmalıdır. Ayrıca çalışmamız da literatürün aksine yoğun insülin tedavisi (4'lü tedavi) alan grubun diyabet kontrolünün daha kötü olduğunu gördük. Bu durum diğer rejimleri alan grupların hasta sayısının az olması ile açıklanabilir. Daha az bir intimalle ise hastaların glisemik kontrolünün diğer tedaviler ile sağlanamadığı için yoğun insülin tedavisine geçilmiş olduğu ya da yoğun insülin tedavisi alan grubun zaten daha büyük yaş grubunda ve daha uzun süreli diyabetli olduğundan glisemik kontrollerinin daha kötü olabileceği düşünüldü. Yirmi dört saatlik kan basıncı ölçümlerinde anlamlı farklılık bulunmamasının sebebi de YIKBi bakılabilen hasta sayısının az olması olabilir. Bu da daha net değerlendirme yapmak için daha fazla hasta ile çalışma yapmamı gerektiği sonucunu ortaya koymaktadır.

\section{KAYNAKLAR}

1. Mayer-Davis EJ, Kahkoska AR, Jefferies C, Dabelea D, Balde N, Gong CX, et al. ISPAD Clinical Practice Consensus Guidelines 2018: Definition, epidemiology, and classification of diabetes in children and adolescents. Pediatr Diabetes 2018; 27(Suppl 27):719.

2. Insel RA, Dunne JL, Atkinson MA, Chiang JL, Dabelea D, Gottlieb PA, et al. Staging presymptomatic type 1 diabetes: a scientific statement of JDRF, the Endocrine Society, and the American Diabetes Association. Diabetes Care 2015;38:1964-74.

3. IDF Diabetes Atlas. 8th ed. Brussels, Belgium: International Diabetes Federation; 2017.IDF. Erişim Tarihi: 14/11/2017. Available from:https://www.diabetesatlas.org/

4. Watkins RA, Evans-Molina C, Blum JS, DiMeglio LA. Established and emerging biomarkers for the prediction of type 1 diabetes: a systematic review. Transl Res 2014;164:110-21.

5. Neyzi O, Bundak R, Gokcay G, Gunoz H, Furman A, Darendeliler F, et al. Reference values for weight, height, head circumference, and body mass index in Turkish Children. J Clin Res Pediatr Endocrinol 2015;7:280-93.

6. Marshall WA, Tanner JM. Variations in the pattern of pubertal changes in girls. Arch Dis Child 1969;44:291-303.

7. Marshall WA, Tanner JM. Variations in the pattern of pubertal changes in boys. Arch Dis Child 1970;45:13-23.

8. Silverstein J, Klingensmith G, Copeland K, Plotnick L, Kaufman $\mathrm{F}$, Laffel L, et al. American Diabetes Association. Care of children 
and adolescents with type 1 diabetes: a statement of the American Diabetes Association. Diabetes Care 2005;28:186-212.

9. Hogg RJ, Furth S, Lemley KV, Portman R, Schwartz GJ, Coresh $\mathrm{J}$, et al. National Kidney Foundation's Kidney Disease Outcomes Quality Initiative. National Kidney Foundation's Kidney Disease Outcomes Quality Initiative clinical practice guidelines for chronic kidney disease in children and adolescents: evaluation, classification, and stratification. Pediatrics 2003;111:1416-21.

10. Wühl E, Witte K, Soergel M, Mehls O, Schaefer F; German Working Group on Pediatric Hypertension. Distribution of 24-h ambulatory blood pressure in children: normalized reference values and role of body dimensions. J Hypertens 2002;20:1995-2007.

11. Şimşek E, Karabay M, Kocabey K. Batı Karadeniz Bölgesinde yaşayan çocuklarda insüline bağımlı diyabetes mellitusun epidemiyolojik özellikleri. Türk Pediatri Arşivi 2003;38: 216-22.

12. Karadağ A, Çelik Y, Toklucu MÖ, Hasbal C, Hatipoğlu S. Bakırköy Dr.Sadi Konuk Eğitim ve Araștırma HastanesiÇocuk sağlığı ve Hastalıkları kliniğinde izlenen tip 1 diyabetes mellituslu çocukların epidemiyolojik özellikleri. ŞEH Tıp Bülteni 2008;42: 17-21.

13. Kandemir N, Açıkgöz E, Yordan N. The Epidemiology of Diabet Onset İnsulin Dependent Diabetes Mellitus in Turkish Children: A Retrospektive Analysis of 477 Cases. Turk J Pediatr 1994; 36: 1915.

14. Derraik JG, Reed PW, Jefferies C, Cutfield SW, Hofman PL, Cutfield WS. Increasing incidence and age at diagnosis among children with type 1 diabetes mellitus over a 20-year period in Auckland (New Zealand). PLoS One 2012;7:e32640.

15. Mahmud FH, Elbarbary NS, Fröhlich-Reiterer E, Holl RW, Kordonouri O, Knip M, Simmons K, Craig ME. ISPAD Clinical Practice Consensus Guidelines 2018: Other complications and associated conditions in children and adolescents with type 1 diabetes. Pediatr Diabetes 2018;19 Suppl 27:275-86.

16. Hughes JW, Riddlesworth TD, DiMeglio LA, Miller KM, Rickels MR, McGill JB. Autoimmune Diseases in Children and Adults With Type 1 Diabetes From the T1D Exchange Clinic Registry. J Clin Endocrinol Metab 2016 Dec;101:4931-7.

17. Ardicli D, Kandemir N, Alikasifoglu A, Ozon A, Gonc N. Clinical characteristics of type 1 diabetes over a 40 year period in Turkey: Secular trend towards earlier age of onset. J Pediatr Endocrinol Metab 2014;27:635-41.

18. DiMeglio LA, Acerini CL, Codner E, Craig ME, Hofer SE, Pillay K, et al. ISPAD Clinical Practice Consensus Guidelines 2018: Glycemic control targets and glucose monitoring for children, adolescents, and young adults with diabetes. Pediatr Diabetes 2018;19 Suppl 27:105-14.

19. Springer D, Dziura J, Tamborlane WV, Steffen AT, Ahern JH, Vincent M, et al. Optimal control of type 1 diabetes mellitus in youth receiving intensive treatment. J Pediatr 2006;149:227-32.

20. Imkampe AK, Gulliford MC. Trends in Type 1 diabetes incidence in the UK in 0- to 14-year-olds and in 15- to 34-year-olds, 19912008. Diabet Med 2011; 28:811-4.

21. Danne T, Phillip M, Buckingham BA, Jarosz-Chobot P, Saboo B, Urakami T, et al. ISPAD Clinical Practice Consensus Guidelines 2018: Insulin treatment in children and adolescents with diabetes. Pediatr Diabetes 2018;19 Suppl 27:115-35.

22. Mortensen HB, Robertson KJ, Aanstoot HJ, Danne T, Holl RW, Hougaard $\mathrm{P}$, et al. Insulin management and metabolic control of type 1 diabetes mellitus in childhood and adolescence in 18 countries. Hvidøre Study Group on Childhood Diabetes. Diabet Med 1998;15:752-9.
23. Diabetes Control and Complications Trial Research Group, Nathan DM, Genuth S, Lachin J, Cleary P, Crofford O, Davis M, et al. The effect of intensive treatment of diabetes on the development and progression of long-term complications in insulin-dependent diabetes mellitus. N Engl J Med 1993;329:977-86.

24. Battaglia M, Anderson MS, Buckner JH, Geyer SM, Gottlieb PA, Kay $\mathrm{TWH}$, et al. Understanding and preventing type 1 diabetes through the unique working model of TrialNet. Diabetologia 2017;60:2139-47.

25. Amin R, Widmer B, Prevost AT, Schwarze P, Cooper J, Edge J, et al. Risk of microalbuminuria and progression to macroalbuminuria in a cohort with childhood onset type 1 diabetes: prospective observational study. BMJ 2008;336:697-701.

26. Krolewski AS. Progressive renal decline: the new paradigm of diabetic nephropathy in type 1 diabetes. Diabetes Care 2015;38:954-62.

27. Rudberg S, Persson B, Dahlquist G. Increased glomerular filtration rate as a predictor of diabetic nephropathy an 8-year prospective study. Kidney Int 1992;41:822-8.

28. Lurbe E, Sorof JM, Daniels SR. Clinical and research aspects of ambulatory blood pressure monitoring in children. $J$ Pediatr 2004;144:7-16.

29. Lurbe E, Redon J, Kesani A, Pascual JM, Tacons J, Alvarez V, et al. Increase in nocturnal blood pressure and progression to microalbuminuria in type 1 diabetes. N Engl J Med 2002;347:797805.

30. Bogdanović R. Diabetic nephropathy in children and adolescents. Pediatr Nephrol 2008;23:507-25.

31. Chiarelli F, Trotta D, Verotti A, Mohn A. Treatment of hypertension an microalbuminuria in children and adolescents with type 1 diyabetes mellitus. Pediatric diabetes 2002:3: 113-24.

32. Levitsky L L, Misra M, Wolfsdorf J I, Hoppin A G.Complications and screening in children and adolescents with type 1 diabetes mellitus. Erişim tarihi: 2009. Avalible from: http://www.uptodate.com

33. Maahs DM, Maniatis AK, Nadeau K, Wadwa RP, McFann K, Klingensmith GJ. Total cholesterol and high-density lipoprotein levels in pediatric subjects with type 1 diabetes mellitus. J Pediatr 2005;147:544-6.

34. Abraha A, Schultz C, Konopelska-Bahu T, James T, Watts A, Stratton IM, et al. Glycaemic control and familial factors determine hyperlipidaemia in early childhood diabetes. Oxford Regional Prospective Study of Childhood Diabetes. Diabet Med 1999;16:598-604.

35. Maahs DM, Wadwa RP, McFann K, Nadeau K, Williams MR, Eckel $\mathrm{RH}$, et al. Longitudinal lipid screening and use of lipid-lowering medications in pediatric type 1 diabetes. J Pediatr 2007;150:14650.

36. Caramori ML, Fioretto P, Mauer M. Enhancing the predictive value of urinary albumin for diabetic nephropathy. J Am Soc Nephrol 2006; 17:339-52.

37. Jenkins AJ, Lyons TJ, Zheng D, Otvos JD, Lackland DT, McGee D, et al. DCCT/EDIC Research Group. Lipoproteins in the DCCT/ EDIC cohort: associations with diabetic nephropathy. Kidney Int 2003;64:817-28.

38. Coonrod BA, Ellis D, Becker DJ, Bunker CH, Kelsey SF, Lloyd $\mathrm{CE}$, et al. Predictors of microalbuminuria in individuals with IDDM. Pittsburgh Epidemiology of Diabetes Complications Study. Diabetes Care 1993;16:1376-83. 